\title{
Assessing government grants: evidence from greenhouse tomato and pepper farmers in Kosovo
}

\author{
Blend FRANGU ${ }^{1}$, Jennie SHEERIN POPP ${ }^{1}$, Michael THOMSEN ${ }^{1}$ and Arben MUSLIU²*
}

Received September 10, 2018; accepted October 27, 2018.

Delo je prispelo 10. septembra 2018, sprejeto 27. oktobra 2018.

\begin{abstract}
Genetic matching with an evolutionary algorithm was applied to evaluate the impact of the Ministry of Agriculture, Forestry and Rural Development (MAFRD) grant programs to support greenhouse vegetable production in Kosovo. The primary contribution of the paper is to assess whether grants have an impact on the farmers' gross seasonal revenue after matching similar grantees to non-grantees. The findings showed that greenhouse tomato grantees make 2,151.80 euros more per growing season in comparison to the non-grantees (95\% confidence interval -324.71 to 4,628.31 euros). Similarly, greenhouse pepper grantees make 2,866.69 euros more per growing season compared to non-grantees (95\% confidence interval 446.42 to $5,286.96$ euros). The study identified farmers' education and region as important matching variables which may be of interest to policy researchers in Kosovo.
\end{abstract}

Key words: greenhouse economics; genetic matching; government farm grants; Kosovo agriculture

\author{
IZVLEČEK \\ UGOTAVLJANJE UČINKOVITOSTI VLADNIH \\ POMOČI: PRIMERI PRIDELOVALCEV \\ PARADIŽNIKA IN PAPRIKE V RASTLINJAKIH NA \\ KOSOVU
}

Genetsko ujemanje in razvojni alagoritem sta bila uporabljena pri vrednotenju vpliva programov pomoči Ministrstva za kmetijstvo, gozdarstvo in razvoj podeželja pri vzpodbujanju pridelave zelenjave v rastlinjakih na Kosovu. Glavni pripevek te raziskave je ocena pomoči na sezonski bruto prihodek kmetov, ki so vladno pomoč dobili v primerjavi s tistimi, ki je niso prejeli. Izsledki so pokazali, da je pomoč pri pridelavi paradižnika v rastlinjakih prispevala 2.151,80 EUR več na sezono v primerjavi s tistimi, ki pomoči niso dobili. (95\% interval zaupanja je znašal $-324,71$ do 4.628,31 EUR). Podobno je pomoč pri pridelavi paprike v rastlinjaku dala za 2.866,69 EUR več na sezono v primerjavi s tistimi, ki pomoči niso dobili (95\% interval zaupanja je bil 446,42 do 5.286,96 EUR). Raziskava je pokazala, da sta izobrazba kmetov in območje pridelave pomembni vplivni spremenljivki, ki bi lahko zanimali raziskovalce agrarne politike na Kosovu.

Ključne besede: ekonomika rastlinjakov; genetsko ujemanje; vladna pomoč kmetom; kmetijstvo Kosova

\section{INTRODUCTION}

The development of Kosovo's agriculture has long been adversely affected by the Kosovo war, a conflict that shaped the dynamics of the agricultural sector and left it vulnerable with large losses of productivity. After the war, the newly formed government of Kosovo invested in agriculture to reestablish a well-functioning economy. Over the last decade, some government investments in the form of competitive grants were targeted to support greenhouse farming. Across Kosovo, tomatoes and peppers are among the main crops grown in greenhouses. In Kosovar greenhouses, tomatoes are more common than peppers (Kaciu, 2008), however, the Ministry of Agriculture, Forestry and Rural Development or MAFRD (2016) suggests that the cultivation of both of these crops have increased since the end of the war.

\footnotetext{
1 Department of Agricultural Economics and Agribusiness, University of Arkansas, Fayetteville, AR 72701, USA

2 Department of Agricultural Economics, Faculty of Agriculture and Veterinary, University of Prishtina "Hasan Prishtina", Pristina, Kosovo. *Corresponding author: arben.musliu@uni-pr.edu
}

This paper is part of the MS thesis of B.F. under the supervision of J.S.P. 
In Kosovo, agricultural production has intensified because of increasing support through grant programs (Miftari et al., 2016). These grants have helped support desperately needed upgrades in farm facilities. These grants may also affect farmers' gross revenue levels, however, details regarding gross revenue changes are lacking. Similarly, reliable evidence regarding the relationship between government financial support and higher gross farm revenue per growing season could be valuable to policy makers. This study considers whether awardees of the MAFRD grants for the purchase of new greenhouses (grantees) have gross seasonal revenues that differ from non-grantees. We chose to examine the tomato and pepper crops because of their increasing levels of production in a greenhouse setting and because tomatoes and peppers remain among the main vegetables produced in Kosovo (Kaciu et al., 2016). In fact, vegetable farms are among the highest income generating farms (Martinovska Stojceska et al., 2008). Understanding the gross revenue impacts of the grant programs are also important given the increasing inequality in productivity between small and large greenhouse tomato and pepper farms. This may be one factor that is leading to different gross seasonal revenue levels.

Governmental reports address the effectiveness of the MAFRD grant programs (MAFRD, 2017), but empirical studies on the effects of these grants to advance the greenhouse vegetable subsector are lacking. Without the backing of empirical evidence, conclusions reached about the effectiveness of MAFRD's provision of grants for the greenhouse farmers can be misleading. It is important to know what factors impact greenhouse tomato and pepper farmers' ability to win grants. One approach to understand the gross revenue differences between farmer grantees and non-grantees is the use of matching to compare grantees to similar non-grantees. There are many methods available to perform matching and no consensus has emerged in the literature as to the best matching method (Stuart, 2010; Ruiz et al., 2017). There are several studies which have reviewed propensity score matching methods (see e.g. D'Agostino, 1998; Terza et al., 2008; Caliendo \& Kopeinig, 2008).

A review of the literature revealed no studies since the early 2000s that have looked at the financial determinants of the greenhouse tomato and pepper production in Kosovo. A matching method known as genetic matching was selected to estimate casual treatment effects of the farmers who received an MAFRD grant. The analysis using this method allows us to quantify the treatment effects of grants on the farmers' gross revenues.

\section{MATERIALS AND METHODS}

\subsection{Data}

The data for the study were obtained from surveys completed by greenhouse tomato and pepper farmers in Kosovo from June to August 2017. Two research surveys (one for each crop) were developed to interview the farmers. There were three steps involved in gathering data from the field: (a) prioritize municipalities and villages with a greater number of farmers growing greenhouse tomatoes and peppers; (b) interview farmers over the age of 18; and (c) evaluate the data for quality and outlying values. The initial sample covered 136 greenhouse farms which, after accounting for data outliers, decreased to 127 greenhouse farms. The farmers producing tomatoes were from the four regions of Ferizaj, Gjakova, Peja and Prizren and those producing peppers were from the four regions of Ferizaj, Gjakova, Peja and Mitrovica.

\subsection{Descriptive Statistics}

The summary statistics of the covariates used for analysis are separated by grant status (grantee or nongrantee) for both greenhouse tomato and pepper farmers
(Table 1). These covariates included distance to market in $\mathrm{km}$, education in years, experience in years, and region indicators that take values of 0 or 1 . The grantees producing tomatoes are located on average $12.9 \mathrm{~km}$ further away from the market than non-grantees and they have roughly two more years of education than non-grantees. However, there is no large difference in years of experience $(0.11$ years $)$ between grantees and non-grantees producing tomatoes. The majority of these grantees $(50 \%)$ are from the region of Prizren. The largest percentage of non-grantees (32\%) are also from the region of Prizren. While grantees producing peppers are located on average only $3.2 \mathrm{~km}$ further away from the market than non-grantees and they have roughly three more years of education than non-grantees. The mean level of experience is 5.75 years among grantees showing that these farmers do not have extensive experience in growing greenhouse peppers. Similarly, non-grantees have only one more year of experience than grantees. Grantees producing peppers come mainly from the region of Peja (38\%), however, non-grantees are mostly from the region of Ferizaj (31\%). 
Table 1: Descriptive statistics of the covariates by grant status

\begin{tabular}{|c|c|c|c|c|c|c|c|c|}
\hline Grant Status & \multicolumn{4}{|c|}{ Grantees } & \multicolumn{4}{|c|}{ Non-Grantees } \\
\hline Covariates $(\mathrm{x})$ & Mean & St. Dev. & Min & Max & Mean & St. Dev. & Min & Max \\
\hline Tomato Farmers & \multicolumn{4}{|c|}{$\mathrm{N}=10$} & \multicolumn{4}{|c|}{$\mathrm{N}=77$} \\
\hline Distance to market in $\mathrm{km}$ & 28.23 & 27.52 & 0.30 & 66 & 15.36 & 14.11 & 0.50 & 62 \\
\hline Education in years & 12.20 & 5.01 & 8 & 20 & 10.48 & 2.95 & 8 & 20 \\
\hline Experience in years & 9.60 & 3.41 & 5 & 17 & 9.71 & 7.72 & 2 & 30 \\
\hline Region of Ferizaj & 0.30 & 0.48 & 0 & 1 & 0.16 & 0.37 & 0 & 1 \\
\hline Region of Gjakova & 0.10 & 0.32 & 0 & 1 & 0.04 & 0.20 & 0 & 1 \\
\hline Region of Peja & 0.10 & 0.32 & 0 & 1 & 0.06 & 0.25 & 0 & 1 \\
\hline Region of Prizren & 0.50 & 0.53 & 0 & 1 & 0.32 & 0.47 & 0 & 1 \\
\hline Pepper Farmers & \multicolumn{4}{|c|}{$\mathrm{N}=8$} & \multicolumn{4}{|c|}{$\mathrm{N}=32$} \\
\hline Distance to market in $\mathrm{km}$ & 28.38 & 20.58 & 10 & 60 & 25.22 & 21.45 & 3 & 84 \\
\hline Education in years & 13.88 & 4.22 & 8 & 20 & 11.06 & 2.65 & 8 & 15 \\
\hline Experience in years & 5.75 & 2.92 & 2 & 9 & 6.41 & 2.80 & 2 & 13 \\
\hline Region of Ferizaj & 0.25 & 0.46 & 0 & 1 & 0.31 & 0.47 & 0 & 1 \\
\hline Region of Gjakova & 0.25 & 0.46 & 0 & 1 & 0.13 & 0.34 & 0 & 1 \\
\hline Region of Peja & 0.38 & 0.52 & 0 & 1 & 0.13 & 0.34 & 0 & 1 \\
\hline Region of Mitrovica & 0.13 & 0.35 & 0 & 1 & 0.09 & 0.30 & 0 & 1 \\
\hline
\end{tabular}

\subsection{Methods}

Early work to develop propensity score matching (PSM) was conducted by Rosenbaum and Rubin (1983), and has become a widely used approach to estimate causal treatment effects (Caliendo \& Kopeinig, 2008). Propensity score matching can be performed using various methods to match subjects. One method includes genetic matching as a multivariate matching method. In this study, the genetic matching algorithm is used to find covariate balance after matching between MAFRD grantees and non-grantees. The implementation of this method enables us to estimate the average treatment effect on the treated (ATT), which we use to assess the average differences in the farmers' gross seasonal revenue between grantees and nongrantees. According to Diamond and Sekhon (2013), genetic matching is performed by reducing a generalized version of the Mahalanobis distance (GMD). In contrast to the Mahalanobis distance, genetic matching includes an extra weight parameter $\mathrm{W}$.

$$
\operatorname{GMD}\left(\mathrm{X}_{\mathrm{i}}, \mathrm{X}_{\mathrm{j}}, \mathrm{W}\right)=\sqrt{\left(\mathrm{X}_{\mathrm{i}}-\mathrm{X}_{\mathrm{j}}\right)^{\mathrm{T}}\left(\mathrm{S}^{-1 / 2}\right)^{\mathrm{T}} \mathrm{WS}^{-1 / 2}\left(\mathrm{X}_{\mathrm{i}}-\mathrm{X}_{\mathrm{j}}\right)}
$$

From equation (1), $X_{i}$ and $X_{j}$ are covariates from farmers $i$ and $j$, respectively. The matrix from the model contains the covariates described in Table $1 . \mathrm{W}$ is a $\mathrm{k} \times \mathrm{k}$ positive definite weight matrix, $\mathrm{S}$ is the sample covariance of matrix $\mathrm{S}$, and $\mathrm{S}^{-1 / 2}$ is the Cholesky decomposition of S (Diamond \& Sekhon, 2013). Replacement was used to ensure that a farmer who received a grant (treatment group) has a proper match with a non-grantee (control group). It is noted in the literature that matching with replacement can provide better matches (Stuart \& Rubin, 2008), and is preferred to use in methods with a control group that has similar values relative to a treatment group (Dehejia \& Wahba, 2002). Lastly, we do our analysis with the help of the RCRAN package "Matching" pioneered by Sekhon (2011).

\subsection{Considerations in covariate selection}

Four factors that we measure may have influence on a MAFRD grantee's ability to match with a non-grantee. The first covariate is distance to market in km. Farmers' markets bring consumers closer to producers (Ling \& Newman, 2011), and the farmer's distance to market may impact both produce quantity and ability to sell the produce in a timely manner. Distance from farm to market can also be an important factor determining the farmer's access to the product markets (Ahmed, et al., 2016).

Agricultural education may influence productivity gains (Fîntîneru \& Madsen, 2012). An earlier study that used propensity score matching found that education was positive and significant for cherry production (Ali et al., 2013). In a later study, education was found to be a contributing factor affecting the farmer's income (Panda, 2015). Based on these previous studies, we concluded that education was an important matching variable. Farm experience is included as a matching variable for similar reasons. Farmers' years of experience vary by region in Kosovo when growing greenhouse tomatoes and peppers. For example, given the strong tradition of tomato production in the region 
of Prizren, it is expected that Prizren greenhouse tomato producers may have more years of farm experience than producers in other regions. For greenhouse pepper producers, however, years of farm experience may differ little from region to region.

Lastly, we consider using covariates to control for four greenhouse tomato and pepper producing regions. Potentially, region may be an important variable in matching MAFRD grantees to non-grantees. For example, Kosovo's regions can have differences in the production of greenhouse vegetable crops because of the climatic conditions, or because of regional differences in family farming traditions. However, reasons may vary as why farmers from one region or another are more or less likely to acquire government farm grants. Therefore, it is important to use the covariate region in the matching procedures.

\section{RESULTS AND DISCUSSION}

When analyzing gross revenue per growing season, it was suggested from both groups of farmers that grantees compared to non-grantees were associated with higher revenue levels (Figure 1). The box plot analysis from Figure 1 shows that farmers producing tomatoes who received MAFRD grants have a mean of 5,759.30 euros while non-grantees have a lower mean of 3,178.84 euros of gross revenue per growing season. Grantees producing peppers suggest a mean of 5,080.43 euros while non-grantees suggest a lower mean of 3,739.02 euros of gross seasonal revenue. Figure 1 indicates also that when observing the densities of both groups of farmers, grantees highlight higher seasonal revenue levels than non-grantees. There were only few grantees producing tomatoes and peppers with gross seasonal revenue greater than $10,000.00$ and less than $3,000.00$ euros. However, there were more non-grantees producing tomatoes and peppers with revenue levels less than 3,000.00 euros. Considering that grants could have a positive impact on farmers' gross seasonal revenues, we estimated possible differences using gross seasonal revenue as the outcome variable in the model. As explained above, covariates including distance to market in $\mathrm{km}$, education in years, and farm experience in years were used in the matching of greenhouse tomato and pepper grantees to non-grantees. Depending on the region, however, farmers were sometimes from different locations. For the matching of greenhouse tomato grantees to non-grantees, we included the regions of Ferizaj, Gjakova, Peja and Prizren. While, the regions of Ferizaj, Gjakova, Peja and Mitrovica were used in the matching of greenhouse pepper grantees to non-grantees. 

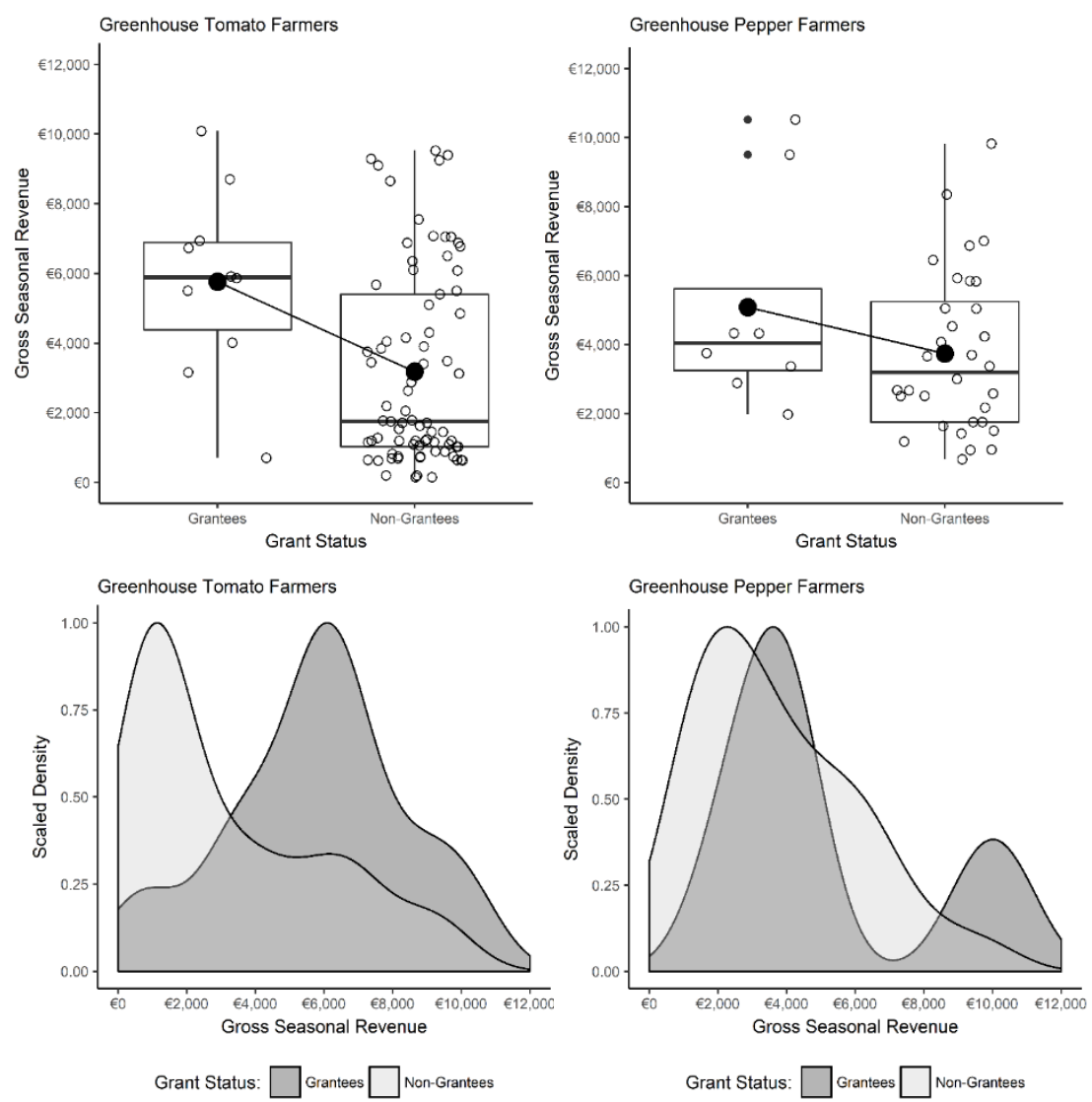

Figure 1: Greenhouse Tomato and Pepper Farmers' Gross Seasonal Revenue Levels

The average treatment effect on the treated (ATT) estimates revealed significant differences in gross seasonal revenue among greenhouse tomato and pepper farmer grantees and non-grantees. There was a statistically significant impact of grants for both greenhouse tomato and pepper farmers (Tables 2 and 3 ). Table 2 shows a positive and marginally significant $(\mathrm{p}<$ 0.1 ) ATT among greenhouse tomato farmers. The estimate of a difference of 2,151.80 euros in gross revenue per growing season was estimated for grantees relative to non-grantees. The $95 \%$ confidence interval is -324.71 to $4,628.31$ euros per growing season. However, it should be noted that the study contains a smaller sample of farmers than was desired. Therefore, ATT results could vary with a larger sample. The findings here suggest that it is possible MAFRD grant programs positively affect gross seasonal revenue levels of greenhouse tomato farmers that were awarded grants.

Table 2: Greenhouse Tomato Grantees' Average Treatment Effect on the Treated

\begin{tabular}{|c|c|c|c|c|c|c|}
\hline \multirow[b]{3}{*}{ Outcome Variable } & \multicolumn{6}{|c|}{ Greenhouse Tomato Grantees } \\
\hline & \multirow[b]{2}{*}{ Unit } & \multirow[b]{2}{*}{ Mean } & \multirow[b]{2}{*}{ T-stat } & \multirow[b]{2}{*}{$\mathrm{p}$-value } & \multicolumn{2}{|c|}{$95 \% \mathrm{CI}$} \\
\hline & & & & & Lower & Upper \\
\hline Gross Seasonal Revenue & & & & & & \\
\hline Estimate & euro & $2,151.80$ & 1.703 & $0.088^{*}$ & -324.71 & $4,628.31$ \\
\hline
\end{tabular}

Note: T-stat, $\mathrm{t}$ statistic; CI, confidence interval. The statistical significance of the estimate is denoted by $* \mathrm{p}<0.1$; $* * \mathrm{p}<0.05 ; * * * \mathrm{p}<0.01$.

Similarly, Table 3 shows a positive and significant $(\mathrm{p}<0.05)$ ATT for greenhouse pepper farmers. The estimate of a difference of $2,866.69$ euros in gross seasonal revenue was suggested for grantees relative to 
non-grantees. The $95 \%$ confidence interval is 446.42 to 5,286.96 euros per growing season. The MAFRD grant programs seem to influence positively the gross seasonal revenue levels of greenhouse pepper farmers.

Table 3: Greenhouse Pepper Grantees' Average Treatment Effect on the Treated

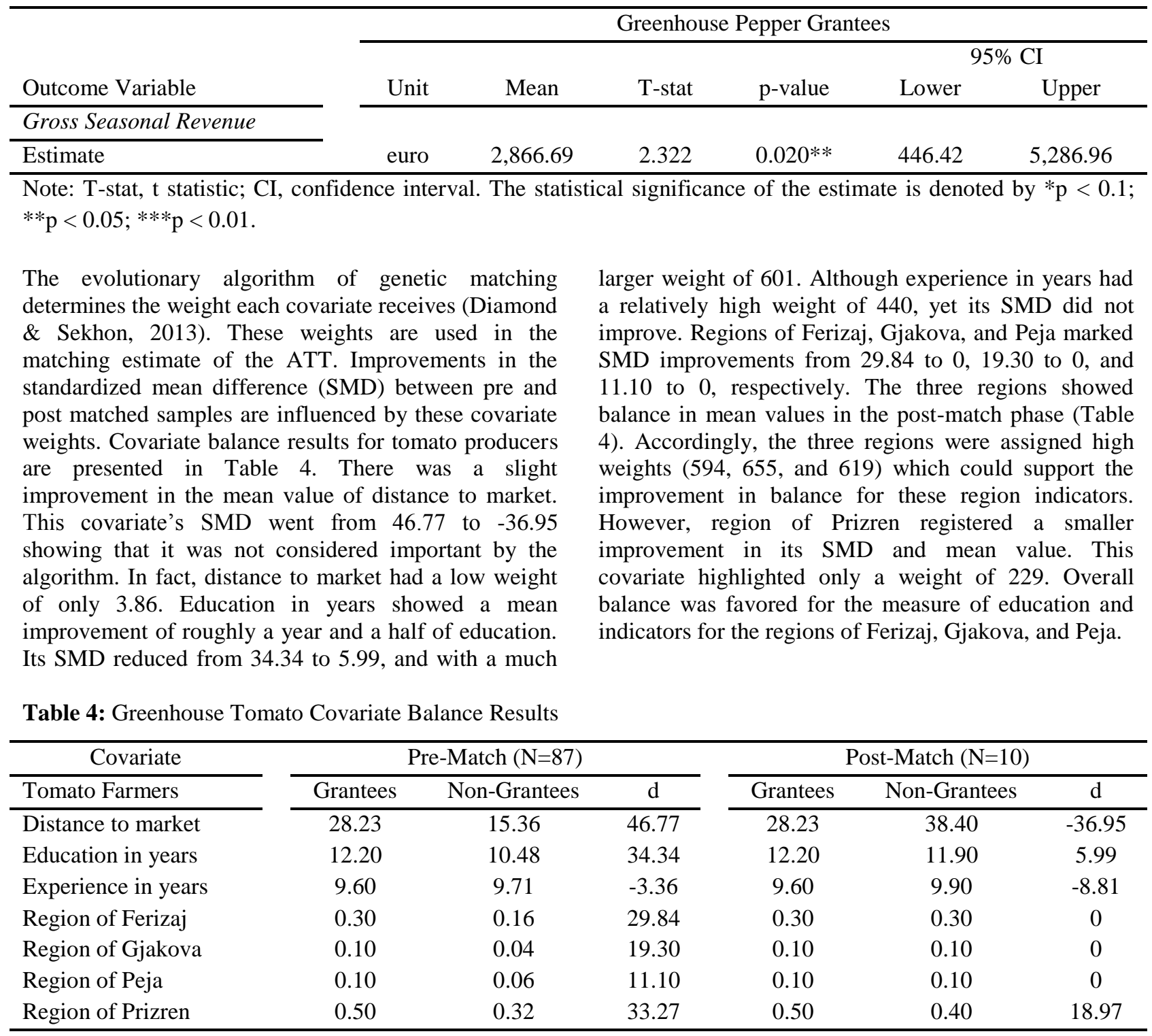

Note: $\mathrm{N}$, number of observations; $\mathrm{d}$, standardized mean difference.

As in the case of tomato farms, distance to market similarly continued to have an imbalance in in the postmatched sample of pepper farms. This measure received a low weight of 126 . Likewise, education in years did not show a large reduction in its mean or SMD. Its SMD decreased from 66.59 to 38.47 and it had a weight of 225. Experience in years had the highest weight (909) and the balance improved from -22.51 to -8.57 . The SMDs of regions of Ferizaj and Gjakova decreased from -13.50 to 0 and 27 to 0 , respectively. The two regions showed balance in the post-match phase (Table 5). In addition, the former region had a weight of 814 and the latter a weight of 899. Region of Peja had a small balance in its mean and SMD and a low weight of 71 . While the mean of region of Mitrovica improved, its SMD degraded from 8.84 to -35.36 . However, this indicator had a very small weight (4.94) among the covariates. In comparison to greenhouse tomato farmers, balance was favored partly for the covariate experience in years and indicators for the regions of Ferizaj and Gjakova. 
Table 5: Greenhouse Pepper Covariate Balance Results

\begin{tabular}{|c|c|c|c|c|c|c|}
\hline Covariate & \multicolumn{3}{|c|}{ Pre-Match $(\mathrm{N}=40)$} & \multicolumn{3}{|c|}{ Post-Match $(\mathrm{N}=8)$} \\
\hline Pepper Farmers & Grantees & Non-Grantees & $d$ & Grantees & Non-Grantees & $\mathrm{d}$ \\
\hline Distance to market & 28.38 & 25.22 & 15.33 & 28.38 & 27.50 & 4.25 \\
\hline Education in years & 13.88 & 11.06 & 66.59 & 13.88 & 12.25 & 38.47 \\
\hline Experience in years & 5.75 & 6.41 & -22.51 & 5.75 & 6.00 & -8.57 \\
\hline Region of Ferizaj & 0.25 & 0.31 & -13.50 & 0.25 & 0.25 & 0 \\
\hline Region of Gjakova & 0.25 & 0.13 & 27.00 & 0.25 & 0.25 & 0 \\
\hline Region of Peja & 0.38 & 0.13 & 48.31 & 0.38 & 0.25 & 24.15 \\
\hline Region of Mitrovica & 0.13 & 0.09 & 8.84 & 0.13 & 0.25 & -35.36 \\
\hline
\end{tabular}

Note: N, number of observations; d, standardized mean difference.

\section{CONCLUSIONS}

The presence of the government grant programs as an agricultural policy may provide the opportunity to promote Kosovo's greenhouse production given that each year more and more farmers apply to the MAFRD grant programs. In this study, important matching variables for greenhouse tomato farmers were education and indicators for the regions of Ferizaj. Gjakova, and Peja. While indicators for the regions of Ferizaj and Gjakova and partly experience in years were most important for greenhouse pepper farmers.

Policy researchers in Kosovo may take interest in the evidence of the positive gross seasonal revenue difference of 2,151.80 euros for the greenhouse tomato grantees relative to the non-grantees, and 2,866.69 euros for the greenhouse pepper grantees relative to the nongrantees. This evidence may help to identify which group of greenhouse farmers are likely to be influenced from the MAFRD grant programs. The study results should also be of interest to nonprofit organizations and agencies for development that invest to help MAFRD's efforts in Kosovo for the provision of new and upgraded farm facilities and greenhouses. Regarding the impact estimates, this study found the genetic matching method with a good convergence of the results with our sample of surveyed farmers. Despite the large or small mean differences of the covariates pertaining to the greenhouse tomato grantees and non-grantees prior to matching, the genetic matching method provided a significant improvement in the covariate balance. Nevertheless, it should be noted that the study contained a sample of farmers that was not sufficiently large, and ATT results could vary with a larger sample.

In conclusion, these overall results suggest that grants awarded to the greenhouse farmers improved their gross revenue levels per growing season. Greenhouse tomato and pepper MAFRD grantees attained higher gross seasonal revenue levels relative to the non-grantees. Considering balance on the covariates, it was found that based on the farmers' education and depending on the region, balance was possible for MAFRD grantees and non-grantees.

\section{REFERENCES}

Ahmed, U. I., Ying, L., Bashir, M. K., Abid, M., Elahi, E. and Iqbal, M. A. (2016). Access to output market by small farmers: The case of Punjab, Pakistan. Journal of Animal and Plant Sciences, 26(3), 787793.

Ali, A., Sharif, M., Mahmood, K. and Akmal, N. (2013). Determinants of cherry production and marketing in Pakistan: A propensity score matching approach. Agricultural Economics Review, 14(1).

Caliendo, M. and Kopeinig, S. (2008). Some practical guidance for the implementation of propensity score matching. Journal of Economic Surveys, 22, 31-72, doi:10.1111/j.1467-6419.2007.00527.x

D'Agostino, R. B. (1998). Propensity score methods for bias reduction in the comparison of a treatment to a non-randomized control group. Statistics in Medicine, 17, 2265-2281, doi:10.1002/(SICI)10970258(19981015)17:19<2265::AIDSIM918>3.0.CO;2-B

Dehejia, R. H. and Wahba, S. (2002). Propensity score matching methods for non-experimental causal studies. The Review of Economics and Statistics, 84, 151-161, doi:10.1162/003465302317331982 
Diamond, A. and Sekhon, J. S. (2013). Genetic matching for estimating causal effects: A general multivariate matching method for achieving balance in observational studies. The Review of Economics and Statistics, 95, 932-945, doi:10.1162/REST_a_00318

Fîntîneru, G. and Madsen, O. (2012). Farmers' education and farm productivity. Evidence from Denmark and from Romania. AgroLife Scientific Journal, 2(1), 175-180.

Kaciu, S. (2008). Study of the current situation of pepper production in Kosovo. Retrieved from http://helvetas-

ks.org/documentation/technical_reports/Study_of_t he_current_situation_of_pepper_production_in_Ko sovo_HPK_Prishtina_35.pdf.

Kaciu, S., Babaj, I., Aliu, S. and Demaj, I. (2016). Potential of protected vegetable production in Kosovo and future perspectives. Acta Hortic, 1142, 461-466, doi:10.17660/ActaHortic.2016.1142.70

Ling, C. and Newman, L. L. (2011). Untangling the Food Web: Farm-to-market distances in British Columbia, Canada. Local Environment, 16, 807822, doi:10.1080/13549839.2010.539602

Martinovska Stojcheska A., Georgiev, N. and Erjavec, E. (2008). Farm income analysis of agricultural holdings in Macedonia using FADN methodology. Acta agriculturae Slovenica, 92(1), 41-51.

Miftari, I., Hoxha, B. and Gjokaj, E. (2016). Kosovo*: Agricultural policy brief $(C A P B)$. Joint Research Centre: Institute for Prospective Technological Studies (IPTS).

Ministry of Agriculture, Forestry and Rural Development. (2016). Green report. Retrieved from http://www.mbpzhrks.net/repository/docs/Green_Report_Kosovo_2016 _Final_050417.pdf.

Ministry of Agriculture, Forestry and Rural Development. (2017). Green report. Retrieved from http://www.mbpzhrks.net/repository/docs/Raporti_i_Gjelber_2017_En g_Final.pdf.

Panda, S. (2015). Farmer education and household agricultural income in rural India. International Journal of Social Economics, 42, 514-529, doi:10.1108/IJSE-12-2013-0278

Ruiz, D., Stout, D. and Herlihy, C. (2017). Use of genetic matching in program evaluation: The case of RAD. Cityscape, 19(2), 337-349.

Sekhon, J. S. (2011). Multivariate and propensity score matching software with automated balance optimization: The Matching package for R. Journal of Statistical Software, 42, 1-52. doi:10.18637/jss.v042.i07

Stuart, E. (2010). Matching methods for causal inference: A review and a look forward. Statistical Science: A Review Journal of the Institute of Mathematical Statistics, 25(1), 1-21, doi:10.1214/09-STS313

Stuart, E. and Rubin, D. B. (2008). Best Practices in Quasi-Experimental Designs: Matching Methods for Causal Inference. Thousand Oaks, CA: SAGE Publications Ltd.

Terza, J. V., Basu, A. and Rathouz, P. J. (2008). Twostage residual inclusion estimation: Addressing endogeneity in health econometric modeling, Journal of Health Economics, 27(3), 531-543, doi:10.1016/j.jhealeco.2007.09.009 